\title{
DIARIUSZ \\ KALENDARIUM WAŻNIEJSZYCH WYDARZEŃ NAUKOWYCH Z UdZiaŁem PRACoWniKóW Wydziąu PraWa, Prawa Kanonicznego i Administracji KUL PAŹDZIERNIK - GRUDZIEŃ 2019 R.
}

\section{Październik}

2-3 października 2019 r. - dr Michał Zawiślak podczas Międzynarodowej Konferencji połączonej ze spotkaniem naukowym członków korespondentów projektu EUREL Mesurer l'appartenance religieuse w Strasburgu wygłosił referat pt. Mesurer l'appartenance religieuse en Pologne.

3 października 2019 r. - dr Paweł Wrzaszcz brał udział w charakterze eksperta w spotkaniu sądów pilotażowych Rady Europy w Barcelonie, podczas którego wygłosił referat pt. System of random assignment of cases to judges in Poland (SLPS).

8 października 2019 r. - odbyła się publiczna obrona rozprawy doktorskiej mgr. Macieja Andrzejewskiego pt. Zasada kontradyktoryjności w systemie kanonicznego prawa procesowego, promotor: dr hab. Marta Greszata-Telusiewicz, prof. KUL.

8 października 2019 r. - odbyła się publiczna obrona rozprawy doktorskiej ks. mgr. Arkadiusza Saternusa pt. Ochrona i obrona praw wiernego w kanonicznym prawie karnym, promotor: ks. dr hab. Krzysztof Mikołajczuk, prof. KUL.

8 października 2019 r. - odbyła się publiczna obrona rozprawy doktorskiej mgr. Pawła Kawki pt. System pomocy rodzinie z osoba niepetnosprawna w latach 2004-2018 w Polsce, promotor: dr hab. Elżbieta Szczot, prof. KUL.

16-17 października 2019 r. - ks. dr hab. Mirosław Sitarz, prof. KUL podczas sesji lubelskiej III Międzynarodowego Kongresu Ruchu Europa Christi Europa dwóch ptuc - Europa Ewangelii, Prawdy i Pokoju nt. Kościót i państwo w stużbie rodziny, pod honorowym patronatem Rzecznika Praw Dziecka, wygłosił referat pt. Prawa i obowiazki rodziny w katolickiej nauce spotecznej. 
17 października 2019 r. - podczas Międzynarodowej Konferencji nt. Krajowe, unijne $i$ międzynarodowe standardy prawnej ochrony zwierząt, odbywającej się na Uniwersytecie Marii Curie-Skłodowskiej, dr hab. Anna Haładyj, prof. KUL wygłosiła referat pt. Jawność informacji o środowisku a ochrona zwierząt. Konflikt interesów prawnie chronionych na przyktadzie udostęniania informacji o środowisku i jego ochronie, natomiast dr Zuzanna Gądzik wygłosiła referat pt. Egzotyka zza krat - ochrona humanitarna zwierząt utrzymywanych w ogrodach zoologicznych.

18 października 2019 r. - odbyła się publiczna obrona rozprawy doktorskiej mgr. Emila Kowalika pt. Zakres kognicji sadu w postępowaniu wieczystoksiegowoym, promotor: dr hab. Joanna Misztal-Konecka, prof. KUL.

21 października 2019 r. - mgr Katarzyna Woch podczas Ogólnopolskiej Konferencji III Seminarium Młodych Procesualistów Cywilnych nt. Aktualne kierunki zmian Kodeksu postępowania cywilnego. Ustawa z 4.7.2019 r. o zmianie ustawy - Kodeks postępowania cywilnego oraz niektórych innych ustaw (Dz.U. z 2019 r., poz. 1469), odbywającej się na Uniwersytecie Rzeszowskim, wygłosiła referat pt. Nowy model postępowania międzyinstancyjnego.

22 października 2019 r. - odbyła się publiczna obrona rozprawy doktorskiej mgr. Kamila Golemy pt. Zaangażowanie pracowników w spótce europejskiej jako forma dialogu społecznego, promotor: ks. dr hab. Włodzimierz Broński.

22 października 2019 r. - odbyła się publiczna obrona rozprawy doktorskiej mgr. Damiana Hermana pt. Administracyjnoprawne aspekty organizowania zgromadzeń, promotor: prof. dr hab. Stanisław Wrzosek.

\section{Listopad}

5-7 listopada 2019 r. - dr Robert Tabaszewski podczas Międzynarodowej Konferencji nt. Legal, ethical and social implications of ageing: towards an international legal framework to adveance the human rights and helarth of older persons, odbywającej się w Genewie i organizowanej przez Brocher Foundation, wygłosił referat pt. Long-term and institutional care for older persons: a global perspective.

12 listopada 2019 r. - odbyła się publiczna obrona rozprawy doktorskiej mgr Magdaleny Machockiej pt. Interes prawny radnego a głosowanie organu stanowiacego jednostki samorzadu terytorialnego, promotor: ks. dr hab. Sławomir Fundowicz.

12 listopada 2019 r. - podczas Konferencji Międzynarodowej nt. Financing of churches and religious societies in the modern democratic state, organizowanej przez Faculty Of Law, Trnava University in Trnava, referaty wygłosili: ks. dr hab. 
Mirosław Sitarz, prof. KUL pt. Kompetencje diecezjalnej rady ekonomicznej i kolegium konsultorów w sprawach finansowych, dr hab. Anna Tunia, prof. KUL pt. Financing Chaplains' Remuneration from the State Budget in Poland, dr Agnieszka Romanko pt. Aspekty finansowe ustawodawstwa papieża Franciszka dotyczace Stolicy Apostolskiej.

13 listopada 2019 r. - podczas Konferencji Międzynarodowej nt. Churches and religious societies in a modern democratic society, organizowanej przez Faculty Of Law, Trnava University in Trnava, referaty wygłosili: ks. dr hab. Mirosław Sitarz, prof. KUL pt. Kształtowanie się relacji między Państwem i Kościołem katolickim w Polsce w latach 1945-1998, dr hab. Anna Tunia, prof. KUL pt. Activity as a Form of Performing Religious Worship in the Law of the Third Republic of Poland, dr Agnieszka Romanko pt. Konkordat polski jako model regulacji relacji państwo-Kościót w czasach wspótczesnych.

15 listopada 2019 r. - dr Judyta Dworas-Kulik podczas Всеукраїнської Наукової Конференціï, odbywającej się we Lwowie, wygłosiła referat pt. The problems of matrimonial law in the Eastern Borderlands of Second Republic of Poland.

18-20 listopada 2019 r. - ks. dr hab. Mirosław Sitarz, prof. KUL podczas sesji Wpływ chrześcijaństwa na stabilność Narodów Europy w ramach III Międzynarodowego Kongresu Ruchu Europa Christi nt. Europa dwóch ptuc - Europa Ewangelii, Prawdy i Pokoju wygłosił referat pt. Wpływ relacji Kościót-państwo na stabilność państwa.

19 listopada 2019 r. - odbyła się publiczna obrona rozprawy doktorskiej ks. mgr. Bronislava Hrynyshyna pt. Recepcja prawa synodalnego Kościoła Rusińskiego na przykładzie dekanatu bełzkiego w latach 1890-1941, promotor: ks. dr hab. Leszek Adamowicz.

19 listopada 2019 r. - dr Robert Tabaszewski podczas Międzynarodowej Konferencji nt. Prawa dziecka w świetle Europejskiej Konwencji Praw Człowieka - XIII Seminarium Warszawskie, odbywającej się w Warszawie i organizowanej przez Ministerstwo Spraw Zagranicznych oraz Rzecznika Praw Dziecka, wygłosił referat pt. Ochrona praw dziecka w środowisku cyfrowym.

20 listopada 2019 r. - dr hab. Anna Haładyj, prof. KUL podczas Ogólnopolskiej Konferencji Naukowej nt. Władza w przestrzeni administracji publicznej, odbywającej się w ramach serii Łódzkie spotkania prawnicze, organizowanej przez Uniwersytet Łódzki, wygłosiła referat pt. Wtadcze i niewładcze działania administracji ochrony środowiska.

21 listopada 2019 r. - dr hab. Paweł Nowik podczas Ogólnopolskiej Konferencja nt. Nowelizacja ustawy o zwiazkach zawodowych - rok po uchwaleniu wygłosił referat pt. Równowaga prawna w sporach zbiorowych. 
21-22 listopada 2019 r. - dr hab. Filip Ciepły podczas Międzynarodowej Konferencji naukowej nt. Criminalisation - Ideas and Restrictions, zorganizowanej przez Trybunał Konstytucyjny w Warszawie, wygłosił referat pt. The Idea of and Limitations to the Criminalisation of Hate Speech.

22 listopada 2019 r. - dr hab. Jacek Widło, prof. KUL podczas Ogólnopolskiej Konferencji w Sądzie Najwyższym w Warszawie wygłosił referat pt. O wspótpracy sędziów zawodowych i sędziów niezawodowych (ławników) przy sporządzaniu uzasadnień orzeczeń - uwag kilka.

25 listopada 2019 r. - odbyła się publiczna obrona rozprawy doktorskiej mgr. Marcina Śliwy pt. Sprawiedliwość warunkowego umorzenia postępowania karnego, promotor: dr hab. Jadwiga Potrzeszcz, prof. KUL.

25-27 listopada 2019 r. - ks. dr Zdzisław Jancewicz podczas II Międzynarodowej Konferencji Naukowej nt. Odrodzenie godności ludzi złotego wieku w ukraińskim społeczeństwie wygłosił referat pt. Socjalno-prawne standardy w zakresie opieki nad seniorami w UE i Polsce.

28-29 listopada 2019 r. - ks. dr hab. Piotr Stanisz, prof. KUL podczas VIII Międzynarodowej Konferencji nt. Sicurezza, legalità, sviluppo: il dialogo euro-mediterraneo, wygłosił referat pt. Integrazione europea, vita democratica e confessioni religiose: a proposito dell'art. 17 del Trattato sul funzionamento dell'Unione Europea.

\section{Grudzień}

4-5 grudnia 2019 r. - podczas IV Ogólnopolskiej Konferencji Naukowej Prawa Medycznego nt. Standardy wykonywania zawodu lekarza oraz innych zawodów medycznych, organizowanej przez Uniwersytet Rzeszowski, referaty wygłosiły: dr Katarzyna Mełgieś pt. Standardy udzielania świadczeń zdrowotnych przez psychologów, dr Katarzyna Miaskowska-Daszkiewicz pt. Stosowanie terapii homeopatycznymi produktami leczniczymi w perspektywie prawnych standardów wykonywania zawodu lekarza.

9 grudnia 2019 r. - mgr Katarzyna Woch podczas Ogólnopolskiej Konferencji nt. Sad w sprawach cywilnych - stan de lege lata i postulaty de lege ferenda, odbywającej się na Uniwersytecie Kardynała Stefana Wyszyńskiego, wygłosiła referat pt. Kompetencje asystenta sędziego w postępowaniu cywilnym.

10 grudnia 2019 r. - dr hab. Anna Kosińska podczas XXXVII Dni Praw Człowieka. Prawa człowieka w perspektywie prawa naturalnego. W stulecie urodzin Hanny 
Waśkiewicz wygłosiła referat pt. Gwarancje realizacji praw kulturalnych cudzoziemców w sytuacjach ekstraordynaryjnych.

13 grudnia 2019 r. - dr Maciej Jarota podczas IV Ogólnopolskiej Konferencji Naukowej nt. Nanotechnologia wobec oczekiwań XXI wygłosił referat pt. Ochrona zdrowia pracownika w środowisku pracy z nanocząstkami - uwagi de lege ferenda $i$ de lege lata.

16 grudnia 2019 r. - dr hab. Filip Ciepły podczas Ogólnopolskiej Konferencji Naukowej nt. Odpowiedzialność prawna o charakterze penalnym za delikty przeciwko środowisku naturalnemu, zorganizowanej przez Katedrę Prawa Karnego Uniwersytetu im. Adama Mickiewicza w Poznaniu, wygłosił referat pt. Aksjologiczne granice prawnej ochrony środowiska naturalnego.

oprac. Pawet Bucoń*

* Dr, Katolicki Uniwersytet Lubelski Jana Pawła II; e-mail: pawel.bucon@kul.pl, https:/ / orcid.org/0000-0002-4413-2588. 
